\title{
Preventing and Arresting the Appearance of White Spot Lesions around the Bracket by applying Fluoride Varnish: A Systematic Review
}

Castaño-Duque Sandra ${ }^{*}$, Díaz Maria ${ }^{1}$, Mora-Díaz Ingrid ${ }^{2}$, Herrera-Díaz Vanessa ${ }^{3}$, Vargas-Ramirez Katia ${ }^{3}$ and Chambrone Leandro ${ }^{4}$

${ }^{1}$ Division of Orthodontics and Epidemiology, Universidad El Bosque, Bogotá D.C, Colombia

${ }^{2}$ Division of Investigation, Universidad El Bosque, Bogotá D.C, Colombia

${ }^{3}$ Department of Orthodontics, Dental School, El Bosque University, Bogotá D.C, Colombia

${ }^{4}$ Unit of Basic Oral Investigations (UIBO), School of Dentistry, El Bosque University, Bogotá, Colombia

\begin{abstract}
Introduction: White spot lesions are the first clinical sign of dental caries, and they occur frequently in patients with orthodontic appliances. Currently, there are no systematic reviews that have evaluated fluoride varnish compared with other methods to prevent or arrest the development of dental caries. The aim of this systematic review (SR) was to evaluate the effectiveness of the use of fluoride varnish compared with other methods to prevent or arrest initial lesions of caries in patients with corrective orthodontics.
\end{abstract}

Methods: A search was conducted for articles in the MEDLINE, EMBASE and Google Scholar databases. This SR included randomized clinical trials and prospective interventional studies that used fluoride varnish for the prevention and/or arrest of white spot lesions in orthodontic treatment or during the 3-month period after removal of orthodontic fixed appliances. To assess the risk of bias in the studies, we used the Cochrane collaboration tool.

Results: The search strategy showed 115 possible eligible articles, and we included 10 articles in this SR. The reviewed studies showed high and moderate methodological quality. Four studies out of 10 agreed that fluoride varnish is as effective as the advised and guided oral hygiene technique. Overall, most of the included studies did not show significant advantages to fluoride varnish application in terms of preventing the development of white spots around orthodontic brackets when the patients were submitted to regular professional oral hygiene control.

Conclusions: Fluoride varnish is an effective material to prevent and arrest white spot lesions in patients with orthodontic treatment.

Keywords: White spot; Orthodontics treatment; Fluoride varnishes; Tooth demineralization; Dental caries; Orthodontics brackets

\section{Introduction}

White spot lesions are the first clinical sign of dental caries that can be clinically detected $[1,2]$. These lesions appear as a result of the cyclic demineralization and remineralization of the enamel due to an alteration in $\mathrm{pH}$ levels when protective factors as saliva and fluorides are not able to maintain a balance in favor of remineralization, resulting in an initial lesion of caries on a specific surface of the tooth [3]. Initial lesions can be arrested and turned into inactive lesions, and the diagnostic can be performed at initial stages using visual inspection after drying the surface [4] with photographs (permanent method to register size of the lesion) and with laser fluorescence (QLF) $[5,6]$ which is a validated method to monitor the early stages of caries and remineralization [7]. Likewise, initial lesions can be detected with diagnodent 8 , which evaluates dental caries through a laser fluorescence detector and is an accurate method to identify caries in pits and fissures, as well as approximal caries. Another method is the International Caries Detection and Assessment System (ICDAS), which is a visual index for detection and classification of caries from white spot lesions to extensive cavities that gives a numerical value ranging from 0 to 6 [8].

Similarly, demineralization has been shown to be a collateral effect associated with poor oral hygiene in patients with a fixed orthodontics appliance [9] due to a greater accumulation of plaque produced by difficulties in performing adequate oral hygiene [1]. Initial lesions can be detected in 2 to 4 weeks as white spots along the periphery of the bracket; in patients with a continuous imbalance between dental plaque and the surface of the tooth, there is a loss of integrity in the surface that results in a cavity $[10,11]$.

Data on the prevalence of initial lesions of caries in patients undergoing orthodontics treatment are variable, i.e., from 2-96\% and $74 \%$ [11]. Studies have indicated that white spot lesions (WSLs) can be controlled and prevented using non-operative treatments, such as fluoride toothpastes, oral rinses, reinforcement of oral hygiene instructions, and topical application of fluorides. Fluoride varnishes can revert, arrest or prevent demineralization processed in a WSL when combined with other preventive measures, such as dental plaque control and diet [12] because of the reduction of demineralization in the surface-reducing enamel solubility $[13,14]$.

Among the products containing fluorides, varnishes are one of the most evaluated agents for remineralization of white spot lesions. The use of varnish increases the time of contact between the enamel, prolongs reactivity of $\mathrm{NaF}$ with the surface of the tooth [15] and is easy to use and secure. Therefore, varnishes have been the first choice for dentists $[16,17]$. The stability of varnishes has been shown for a period of 3 months, and the benefits can be the result of the $\mathrm{CaF}_{2}$ precipitation that favors remineralization [18].

Currently, there are no systematic reviews that evaluated the effectiveness of fluoride varnishes in preventing and arresting white

*Corresponding author: Dr. Sandra Castaño Duque, Associate Professor Epidemiologist, Orthodontist, El Bosque University, Bogotá D.C, Colombia, Tel: (+57)310-294-72-82; E-mail: sandracastanoduque@gmail.com

Received July 10, 2018; Accepted July 16, 2018; Published July 22, 2018

Citation: Sandra CD, Maria D, Ingrid MD, Vanessa HD, Katia VR, et al. (2018) Preventing and Arresting the Appearance of White Spot Lesions around the Bracket by applying Fluoride Varnish: A Systematic Review. Dentistry 8: 500 doi:10.4172/2161-1122.1000500

Copyright: ( 2018 Sandra CD, et al. This is an open-access article distributed under the terms of the Creative Commons Attribution License, which permits unrestricted use, distribution, and reproduction in any medium, provided the original author and source are credited. 
Citation: Sandra CD, Maria D, Ingrid MD, Vanessa HD, Katia VR, et al. (2018) Preventing and Arresting the Appearance of White Spot Lesions around the Bracket by applying Fluoride Varnish: A Systematic Review. Dentistry 8: 500. doi:10.4172/2161-1122.1000500

spot lesions around the brackets compared with other preventive methods.

\section{Objective}

The aim of this systematic review was to assess the effectiveness of fluoride varnish applications compared with other techniques for the prevention or arrest of initial lesions of caries in patients with corrective orthodontics.

Consequently, the following research PICO question was suggested: Is the fluoride varnish application effective compared with other techniques to prevent or arrest white spot lesions in patients with corrective orthodontics?

\section{Materials and Methods}

This review was structured according to the guidelines of PRISMA [19], the Cochrane Handbook for Systematic Reviews of Intervention [20] and the checklist for reviews [21]. Likewise, the protocol for this SR was registered at the National Institute for Health Research PROSPERO, International Prospective Registry of Systematic Reviews (http://www.crd.york.ac.uk/PROSPERO, registration number CRD42016038888).

\section{Type of study and participants (inclusion criteria)}

This review included all articles that met the following criteria: studies on human, controlled clinical trials and prospective intervention studies that compared the effectiveness of fluoride varnish applications versus other techniques to prevent or arrest white spot lesions in patients with permanent dentition undergoing corrective orthodontics treatment or after removal of orthodontic fixed appliances in a time less than or equal to 3 months.

\section{Exclusion criteria}

Authors discarded studies that evaluated the effectiveness of fluoride varnish on teeth with orthodontics bands or loops, cavitational caries, dental whitening, enamel defects, dental restorations in the buccal surface and lesions microscopically assessed. Likewise, we excluded studies that evaluated the effectiveness of simultaneous application of a fluoride varnish with another product.

\section{Measurement of results}

This review evaluated the following variables of the results:

1) Prevention of white spot lesions, measured by visual clinical examination and other visual diagnostic tests.

2) Arrest of white spot lesions, measured by visual clinical examination and other visual diagnostic tests.

\section{Search strategies}

Detailed search strategies were developed for MEDLINE (for Medical Literature Analysis and Retrieval System Online), EMBASE (Excerpta Medica Database), Google Scholar, as well as other sources of information such as the gray literature and manual search.

There was no restriction of language. Databases were reviewed until February 2017 using MeSH terms (Medical Subject Headings), keywords and other free terms with Boolean operators (OR, AND).

Search strategies were based on the algorithm used for MEDLINE:

\#1 orthodontics or orthodontics treatment or orthodontics brackets or multibrackets appliance therapy
\#2 white spot or dental caries or tooth demineralization

$\# 3 \# 1$ and \#2

\#4 topical fluoride or fluoride varnishes or varnishes, fluoride or varnishes or fluoride or fluor protector or remineralizing agents

\#5 prevention or prevention and control

\#6 \#4 or \#5

$\# 7 \# 3$ and \#6

\section{Validity assessment and data extraction}

Two independent reviewers evaluated titles, abstracts and full texts of the articles and disagreement between reviewers was resolved through discussion. When no agreement could be reached, a third reviewer was consulted. If important data were missing or unclear, we attempted to contact the authors to resolve the ambiguity of the information. Information from the articles was extracted and recorded taking into account the following data: year of publication, location of the trial, study design, characteristics of the participants, measure of outcomes, methodological quality of the trials and conclusions.

\section{Assessment of risk of bias and quality assessment in included studies}

The methodological quality of the randomized clinical trials and prospective intervention studies was evaluated using the Cochrane Collaboration tool for assessing risk of bias, as described in the Cochrane Handbook for Systematic Reviews [20,21] (Table 1).

The risk of bias was classified according to the following characteristics:

(1) low risk of bias: all criteria were achieved (adequate methods of randomization and concealment of allocation, adequate follow-up, blinding of examiners);

(2) uncertain risk of bias: one or more criteria partially achieved (i.e., unclear criteria were established); or

(3) high risk of bias: one or more criteria were not achieved [21].

\section{Data synthesis}

Data were grouped into tables of evidence, and a descriptive summary was created to determine the quantification of data and variations of the studies.

\section{Results}

\section{Search results}

The search strategy identified 817 potentially eligible articles in the database (Embase, PubMed y Google Scholar). Then, 701 articles were excluded based on the title of each article, and 116 abstracts from the remaining articles were analyzed and 94 were excluded; 22 full texts were then analyzed and 12 were excluded due to the selection criteria not being met (Figure 1).

\section{Included studies}

A total of 10 clinical trials were selected for this systematic review that were conducted in the United States [22,23] Brazil [24-26] Sweden [27], Iran [28], Germany [29], China [30] and Italy [31]. Three of the studies used fluoride varnish as a preventive therapy in the appearance of white spot lesions around the bracket $[24,25,31]$ with a split mouth design, and 7 studies used varnish to treat white spot lesions around the bracket with a parallel design $[22,23,26-30]$. 
Citation: Sandra CD, Maria D, Ingrid MD, Vanessa HD, Katia VR, et al. (2018) Preventing and Arresting the Appearance of White Spot Lesions around the Bracket by applying Fluoride Varnish: A Systematic Review. Dentistry 8: 500. doi:10.4172/2161-1122.1000500

Page 3 of 10

\begin{tabular}{|c|c|c|}
\hline Domain & Support for judgement & Review authors' judgement \\
\hline \multicolumn{3}{|c|}{ Selection bias } \\
\hline Random sequence generation. & $\begin{array}{l}\text { Describe the method used to generate the allocation sequence in sufficient detail to } \\
\text { allow an assessment of whether it should produce comparable groups. }\end{array}$ & $\begin{array}{c}\text { Selection bias (biased allocation to interventions) } \\
\text { due to inadequate generation of a randomised } \\
\text { sequence. }\end{array}$ \\
\hline Allocation concealment. & $\begin{array}{l}\text { Describe the method used to conceal the allocation sequence in sufficient detail to } \\
\text { determine whether intervention allocations could have been foreseen in advance of, } \\
\text { or during, enrolment. }\end{array}$ & $\begin{array}{l}\text { Selection bias (biased allocation to interventions) } \\
\text { due to inadequate concealment of allocations } \\
\text { prior to assignment. }\end{array}$ \\
\hline \multicolumn{3}{|c|}{ Performance bias } \\
\hline $\begin{array}{c}\text { Blinding of participants and } \\
\text { personnel Assessments should } \\
\text { be made for each main outcome } \\
\text { (or class of outcomes). }\end{array}$ & $\begin{array}{c}\text { Describe all measures used, if any, to blind study participants and personnel from } \\
\text { knowledge of which intervention a participant received. Provide any information } \\
\text { relating to whether the intended blinding was effective. }\end{array}$ & $\begin{array}{l}\text { Performance bias due to knowledge of the } \\
\text { allocated interventions by participants and } \\
\text { personnel during the study. }\end{array}$ \\
\hline \multicolumn{3}{|c|}{ Detection bias } \\
\hline $\begin{array}{c}\text { Blinding of outcome } \\
\text { assessment Assessments } \\
\text { should be made for each main } \\
\text { outcome (or class of outcomes). }\end{array}$ & $\begin{array}{c}\text { Describe all measures used, if any, to blind outcome assessors from knowledge of } \\
\text { which intervention a participant received. Provide any information relating to whether } \\
\text { the intended blinding was effective. }\end{array}$ & $\begin{array}{l}\text { Detection bias due to knowledge of the allocated } \\
\text { interventions by outcome assessors. }\end{array}$ \\
\hline \multicolumn{3}{|c|}{ Attrition bias } \\
\hline $\begin{array}{c}\text { Incomplete outcome data } \\
\text { Assessments should be made } \\
\text { for each main outcome (or class } \\
\text { of outcomes). }\end{array}$ & $\begin{array}{l}\text { Describe the completeness of outcome data for each main outcome, including } \\
\text { attrition and exclusions from the analysis. State whether attrition and exclusions were } \\
\text { reported, the numbers in each intervention group (compared with total randomized } \\
\text { participants), reasons for attrition/exclusions where reported, and any re-inclusions in } \\
\text { analyses performed by the review authors. }\end{array}$ & $\begin{array}{l}\text { Attrition bias due to amount, nature or handling } \\
\text { of incomplete outcome data. }\end{array}$ \\
\hline \multicolumn{3}{|c|}{ Reporting bias } \\
\hline Selective reporting. & $\begin{array}{c}\text { State how the possibility of selective outcome reporting was examined by the review } \\
\text { authors, and what was found. }\end{array}$ & $\begin{array}{l}\text { Reporting bias due to selective outcome } \\
\text { reporting. }\end{array}$ \\
\hline \multicolumn{3}{|c|}{ Other bias } \\
\hline \multirow{2}{*}{ Other sources of bias. } & $\begin{array}{l}\text { State any important concerns about bias not addressed in the other domains in the } \\
\text { tool. }\end{array}$ & \multirow{2}{*}{$\begin{array}{l}\text { Bias due to problems not covered elsewhere in } \\
\text { the table. }\end{array}$} \\
\hline & $\begin{array}{l}\text { If particular questions/entries were pre-specified in the review's protocol, responses } \\
\text { should be provided for each question/entry. }\end{array}$ & \\
\hline
\end{tabular}

Table 1: Cochrane Collaboration tool for assessing risk of bias.

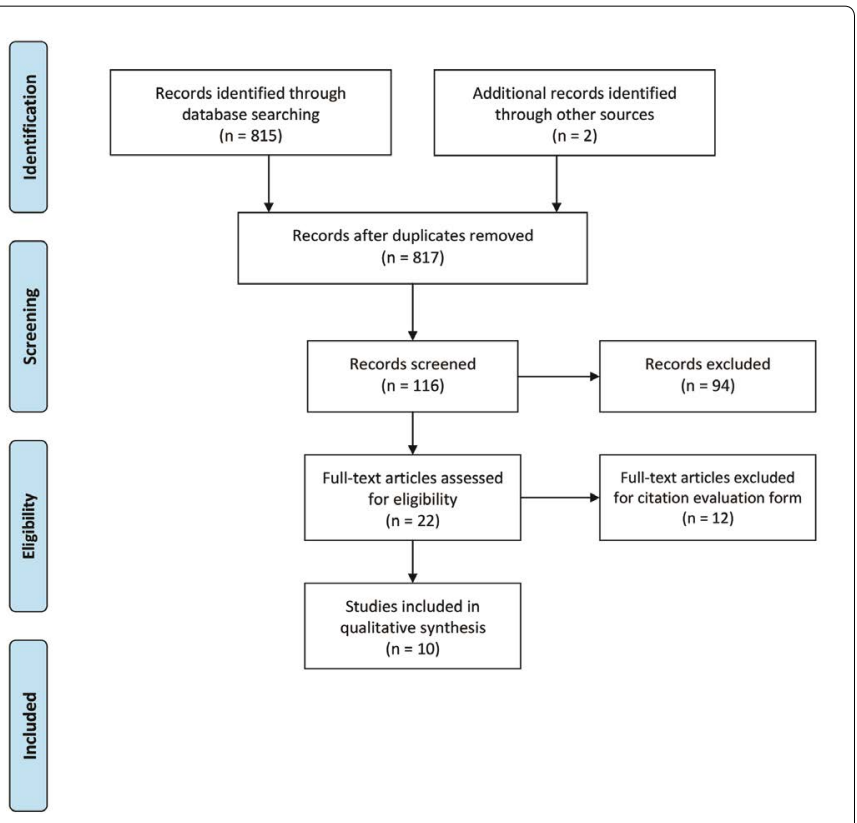

Figure 1: Study selection flow diagram of the systematic review.

Articles were published between 2006 and 2016; 6 articles were randomized controlled trials [22,23,26-30] and 4 were non-randomized clinical trials $[24,25,28,31]$ (Tables 2 and 3 ).

Altogether, 866 subjects were examined in the evaluated articles. It is noteworthy that the following visual diagnostic methods were used to measure the effectiveness of fluoride varnish: Diagnodent [24,26,31] clinical photographs, QLF, QLF and ICDAS, ICDAS, and Nyvad index [23-28].

Methodological quality of the included studies, assessment of the effectiveness of fluoride varnish to prevent and arrest white spot lesions:

Evaluation of studies: Six studies showed high methodological quality [22,23,26-30], and four showed moderate methodological quality $[24,25,28,31]$. Additionally, eight clinical trials showed adequate methods of randomization, and six studies [22,23,26-30] described clear and adequate allocation concealment as well as results regarding the completeness of the follow-up. Only four clinical trials reported blinding of examiners and participants [23,26,29,30]. Regarding "selective outcome reporting" and "sources of bias", information was not clear for the trials $[25,28]$ (Figure 2). The follow-up period ranged from approximately 0 months to a year, considering that some articles had time intervals of 3 -months [24,25,30,31].

Assessment of the effectiveness of fluoride varnish to prevent white spot lesions: According to Demito et al. [24] teeth not treated with fluoride varnish showed a greater tendency to demineralize, 0.89 $+/-1.94$ in the control group vs $0.53+/-1.33(p<0.05)$ in the varnish group. Rodrigues et al. [25], reported similar results with an increase of $0.34+/-0.64$ in the experimental group and $0.61+/-1.15$ in the control group; for both studies, these differences were statistically significant. The study carried out by Huang et al. [23] found no differences between MI Paste Plus and PreviDent fluoride varnish compared to a 
Citation: Sandra CD, Maria D, Ingrid MD, Vanessa HD, Katia VR, et al. (2018) Preventing and Arresting the Appearance of White Spot Lesions around the Bracket by applying Fluoride Varnish: A Systematic Review. Dentistry 8: 500. doi:10.4172/2161-1122.1000500

\begin{tabular}{|c|c|c|c|c|c|c|}
\hline Study & $\begin{array}{c}\text { Participants /Type } \\
\text { of material/ study } \\
\text { design }\end{array}$ & Groups & $\begin{array}{l}\text { Postoperative } \\
\text { Follow Up }\end{array}$ & $\begin{array}{l}\text { Postoperative } \\
\text { sensitivity } \\
\text { evaluation }\end{array}$ & Outcome & Conclusions \\
\hline \multicolumn{7}{|c|}{ Demito et al., [21] } \\
\hline & $\begin{array}{c}15 \text { patients ( } 274 \\
\text { teeth). }\end{array}$ & \multirow{2}{*}{$\begin{array}{c}\text { Test group: } \\
137 \text { teeth } \\
\text { Fluoride varnish } \\
\text { application } \\
\text { Duraphat. }\end{array}$} & \multirow{5}{*}{$\begin{array}{l}\text { Measures at } 3 \\
\text { months and } 6 \\
\text { months after } \\
\text { application. }\end{array}$} & $\begin{array}{c}0-10=\text { sound } \\
\text { dental surface. }\end{array}$ & \multirow{2}{*}{$\begin{array}{l}\text { Control group showed } 32 \% \text { more } \\
\text { progression of demineralization } \\
\text { than varnish group at } 6 \text { months, no } \\
\text { significance. }\end{array}$} & \multirow{5}{*}{$\begin{array}{l}\text { The fluoride varnish is less expensive } \\
\text { and easier to apply than fluoride gel } \\
\text { and unlike home rinses, this do not } \\
\text { require patient collaboration. The } \\
\text { disadvantages include the need to wait } \\
1 \text { hour before eating or drinking and } \\
12 \text { hours before brushing, re-apply } \\
\text { the varnish at least every } 12 \text { weeks to } \\
\text { maintain its effectiveness. At the end, } \\
\text { when comparing fluoride varnish with } \\
\text { other alternatives to reduce enamel } \\
\text { decalcification, varnishes can be the } \\
\text { first option. }\end{array}$} \\
\hline & $\begin{array}{l}\text { Fluoride varnish } \\
\text { Duraphat/ Without } \\
\text { fluoride varnish. }\end{array}$ & & & $\begin{array}{c}11-20=\text { caries in } \\
\text { enamel (external } \\
\text { half). }\end{array}$ & & \\
\hline & $\begin{array}{l}\text { Randomized Clinical } \\
\text { Trial. }\end{array}$ & & & $\begin{array}{c}21-30=\text { caries in } \\
\text { enamel (internal } \\
\text { half) }\end{array}$ & $\begin{array}{c}\text { Most of the demineralization was in the } \\
\text { gingival third. }\end{array}$ & \\
\hline & \multirow[b]{2}{*}{ Split-Mouth. } & \multirow{2}{*}{$\begin{array}{l}\text { Control group: } \\
137 \text { teeth, } \\
\text { no Fluoride } \\
\text { application. }\end{array}$} & & $>30=$ caries & Teeth without intervention. & \\
\hline & & & & Diagnodent. & Gingival third: $0.89+/-1.94$ & \\
\hline \multicolumn{7}{|c|}{ Perrini et al., [25] } \\
\hline & 24 patients. & \multirow{3}{*}{$\begin{array}{l}\text { Test group: } \\
\text { Quadrant } 1 \text { and } 3 \\
\text { using Duraphat. }\end{array}$} & \multirow{4}{*}{$\begin{array}{l}\text { Evaluation at the } \\
\text { intervention, } 3, \\
6,9, \text { y } 12 \text { months } \\
\text { after placing } \\
\text { brackets. }\end{array}$} & $\begin{array}{l}0 \text { a 13: sound } \\
\text { enamel. }\end{array}$ & \multirow{3}{*}{$\begin{array}{l}\text { The sample showed a greater tendency } \\
\text { to demineralization in the untreated } \\
\text { vs treated teeth, although both linear } \\
\text { analyzes and coefficient showed not } \\
\text { significant difference at any of the } \\
\text { measured times. Conclusions indicate } \\
\text { that the gingival third was slightly more } \\
\text { susceptible to demineralization. }\end{array}$} & \multirow{4}{*}{$\begin{array}{c}\text { Regular application of fluoride varnish } \\
\text { may protect against white spots, but will } \\
\text { not be statistically significant if patients } \\
\text { have excellent oral hygiene. }\end{array}$} \\
\hline & $\begin{array}{l}\text { Duraphat/ without } \\
\text { fluoride varnish. }\end{array}$ & & & $\begin{array}{c}14 \text { a } 20: \text { initial } \\
\text { demineralization. }\end{array}$ & & \\
\hline & $\begin{array}{l}\text { Randomized Clinical } \\
\text { Trial. }\end{array}$ & & & $\begin{array}{c}21 \text { a 29: } \\
\text { moderate } \\
\text { demineralization. }\end{array}$ & & \\
\hline & Split-Mouth. & $\begin{array}{l}\text { Control group: } \\
\text { Quadrants } 2 \\
\text { and 4, without } \\
\text { fluoride varnish. }\end{array}$ & & $\begin{array}{l}>30: \text { dental } \\
\text { caries. }\end{array}$ & $\begin{array}{l}\text { Particularly, at } 9 \text { months, incisors } \\
\text { treated with fluoride varnish showed } \\
\text { significantly less demineralization } \\
\text { compared to non-treated teeth. }\end{array}$ & \\
\hline \multicolumn{7}{|c|}{ Rodrigues et al., [26] } \\
\hline & $\begin{array}{l}10 \text { patients }(200 \\
\text { teeth). }\end{array}$ & \multirow{2}{*}{$\begin{array}{l}\text { Test group: } \\
100 \text { teeth } \\
\text { with Duraflor } \\
\text { application. }\end{array}$} & \multirow{5}{*}{$\begin{array}{c}\text { Varnish was } \\
\text { applied every } 3 \\
\text { months during a } \\
\text { year. }\end{array}$} & $\begin{array}{c}0: \text { without } \\
\text { decalcification }\end{array}$ & \multirow{3}{*}{$\begin{array}{c}\text { The average number of varnish } \\
\text { application was } 10 \text { (range } 4-20 \text { ) in } \\
\text { both groups. Incidence of WSL during } \\
\text { treatment with orthodontic fixed } \\
\text { appliances was } 7.4 \% \text { in the fluoride } \\
\text { varnish group compared to the placebo } \\
\text { group } 25.3 \% \text { (P } 0.001 \text { ). The absolute } \\
\text { risk reduction was } 18 \% \text {. }\end{array}$} & \multirow{3}{*}{$\begin{array}{l}\text { The results of this prospective } \\
\text { evaluation of quarterly application of } \\
\text { fluoride varnish have shown to be an } \\
\text { effective auxiliary method to reduce } \\
\text { white spot lesions during treatment } \\
\text { with orthodontic fixed appliances. } \\
\text { During a } 12-\text { month observation, there } \\
\text { was a } 44.3 \% \text { reduction in enamel } \\
\text { demineralization index of teeth treated } \\
\text { with fluoride varnish compared to } \\
\text { control group. }\end{array}$} \\
\hline & $\begin{array}{l}\text { Duraflor/ without } \\
\text { fluoride varnish. }\end{array}$ & & & $\begin{array}{l}\text { 1: decalcification } \\
\text { less than } 50 \% \text { of } \\
\text { the Surface. }\end{array}$ & & \\
\hline & $\begin{array}{l}\text { Randomized clinical } \\
\text { trial. }\end{array}$ & \multirow{3}{*}{$\begin{array}{l}\text { Control group: } \\
100 \text { teeth without } \\
\text { fluoride varnish } \\
\text { application. }\end{array}$} & & $\begin{array}{l}\text { 2: decalcification } \\
\text { greater than } 50 \% \\
\text { of the surface. }\end{array}$ & & \\
\hline & Split-Mouth. & & & $\begin{array}{l}\text { 3: decalcification } \\
100 \% \text { of } \\
\text { the surface, } \\
\text { or severe } \\
\text { decalcification } \\
\text { with cavity. }\end{array}$ & \multirow{2}{*}{$\begin{array}{c}\text { Progression was significantly lower in } \\
\text { fluoride varnish group than the placebo } \\
\text { group, } 0,8+/-2,0 \text { vs. } 2,6+/-2,8 \text { (P } \\
0.001)\end{array}$} & \multirow{2}{*}{$\begin{array}{l}\text { Although fluoride varnish does not } \\
\text { completely prevent the development } \\
\text { of enamel lesions, the reduce in the } \\
\text { incidence and severity of the lesions } \\
\text { deserves a clinical consideration. The } \\
\text { regular application of fluoride varnish } \\
\text { in patients undergoing orthodontic } \\
\text { treatment can be accepted as a } \\
\text { contemporary standard of care to limit } \\
\text { enamel lesions. }\end{array}$} \\
\hline & & & & $\begin{array}{l}\text { Banks and } \\
\text { Richmond } \\
\text { index through } \\
\text { photographs. }\end{array}$ & & \\
\hline
\end{tabular}

Table 2: Characteristics of included studies in preventing white spot lesions with fluoride varnish application.

\begin{tabular}{|c|c|c|c|c|c|c|}
\hline Study & $\begin{array}{l}\text { Participants } \\
\text { /Type of } \\
\text { material/ study } \\
\text { design }\end{array}$ & Groups & $\begin{array}{l}\text { Postoperative } \\
\text { Follow Up }\end{array}$ & $\begin{array}{l}\text { Postoperative } \\
\text { sensitivity } \\
\text { evaluation }\end{array}$ & $x_{1}^{2}$ & Conclusions \\
\hline \multicolumn{2}{|c|}{ Huang et al., [30] } & & \multirow{4}{*}{$\begin{array}{l}\text { Measures in } \\
\text { the } 8^{\text {th }} \text { week of } \\
\text { intervention }\end{array}$} & \multirow{2}{*}{$\begin{array}{l}\text { 0: without } \\
\text { improvement or } \\
\text { deterioration }\end{array}$} & \multirow{3}{*}{$\begin{array}{l}\text { The measures evaluated by the } \\
\text { expert panel were } 21 \% \text { MI Paste } \\
\text { Plus, } 29 \% \text { PreviDent and } 27 \% \text { in } \\
\text { the control group. The results of } \\
\text { the expert panel were } 29 \%, 31 \% \text {, } \\
\text { and } 25 \% \text {, respectively. Scores } \\
\text { for objective improvements were } \\
16 \%, 25 \% \text { and } 17 \% \text {, and scores for } \\
\text { autopercieved improvement were } \\
37 \% \text { in the } 3 \text { groups. }\end{array}$} & \multirow{4}{*}{$\begin{array}{l}\text { In this randomized clinical trial, } \\
\text { there was no difference between } \\
\text { the effectiveness of MI Paste Plus, } \\
\text { fluoride varnish PreviDent compared } \\
\text { with conventional and toothpaste } \\
\text { regimen for remineralization of white } \\
\text { spots during a period of } 8 \text { weeks. }\end{array}$} \\
\hline \multirow{2}{*}{\multicolumn{2}{|c|}{$\begin{array}{l}\text { MI Paste Plus/ Fluoride } \\
\text { varnish PreviDent/ without } \\
\text { fluoride varnish }\end{array}$}} & $\begin{array}{l}\text { Test group 1: } 34 \text { patients, } \\
\text { application of MI Paste Plus }\end{array}$ & & & & \\
\hline & & $\begin{array}{l}\text { Test group 2: } 40 \text { patients, } \\
\text { application of } 0.4 \mathrm{~mL} \text { of } \\
\text { 5\% sodium fluoride varnish } \\
\text { PreviDent }\end{array}$ & & $\begin{array}{l}\text { 100: completely } \\
\text { improved in mm }\end{array}$ & & \\
\hline & $\begin{array}{l}\text { Randomized } \\
\text { clinical trial }\end{array}$ & $\begin{array}{l}\text { Control group: } 41 \text { teeth, } \\
\text { without fluoride varnish }\end{array}$ & & Photographs & No significant differences & \\
\hline \multicolumn{7}{|c|}{ Stecksén et al., [20] } \\
\hline
\end{tabular}


Citation: Sandra CD, Maria D, Ingrid MD, Vanessa HD, Katia VR, et al. (2018) Preventing and Arresting the Appearance of White Spot Lesions around the Bracket by applying Fluoride Varnish: A Systematic Review. Dentistry 8: 500. doi:10.4172/2161-1122.1000500

\begin{tabular}{|c|c|c|c|c|c|}
\hline 302 patients & \multirow{2}{*}{$\begin{array}{l}\text { Test group: } 132 \text { patients. } \\
\text { Application of Fluor } \\
\text { protector } 0.1 \% \mathrm{~F} \text { with silane } \\
\text { fluoride varnish based on } \\
\text { polyurethane. }\end{array}$} & \multirow{5}{*}{$\begin{array}{l}\text { Until complete } \\
\text { orthodontic } \\
\text { treatment }\end{array}$} & $\begin{array}{c}\text { 1: No } \\
\text { development of } \\
\text { white spot }\end{array}$ & \multirow{2}{*}{$\begin{array}{l}\text { The incidence of WSL during } \\
\text { treatment with an orthodontic fixed } \\
\text { appliance in the fluoride varnish } \\
\text { group was approximately one-third } \\
\text { of the placebo group, } 7,4 \text { vs. } 25.7 \% \\
\text { (P<0.05). }\end{array}$} & \multirow{5}{*}{$\begin{array}{l}\text { The results of this study strongly } \\
\text { suggest that regular applications } \\
\text { of fluoride varnish may reduce the } \\
\text { development of white spot lesions } \\
\text { around the bracket during treatment } \\
\text { with orthodontic fixed appliances. } \\
\text { Therefore, fluoride varnishes should } \\
\text { be advocated as a professional } \\
\text { preventive measure in orthodontic } \\
\text { practice. }\end{array}$} \\
\hline $\begin{array}{l}\text { Fluoride varnish Duraphat/ } \\
\text { without fluoride varnish }\end{array}$ & & & $\begin{array}{c}\text { 2: mild } \\
\text { development of } \\
\text { white spot (thin } \\
\text { border) }\end{array}$ & & \\
\hline Randomized clinical trial & \multirow{3}{*}{$\begin{array}{l}\text { Control group: } 125 \text { patients. } \\
\text { Application of a colorless } \\
\text { varnish placebo similar to } \\
\text { the one used in the treated } \\
\text { group but without fluoride. }\end{array}$} & & $\begin{array}{c}\text { 3: severe } \\
\text { development of } \\
\text { white spot (thick } \\
\text { band) }\end{array}$ & \multirow{3}{*}{$\begin{array}{l}\text { The mean score of progression } \\
\text { was } 0.8 \pm 2.0 \text { in the intervention } \\
\text { group compare with } 0.8 \pm 2.0 \text { in the } \\
\text { control group; this difference was } \\
\text { statistically significant }(P<0.001) \text {. }\end{array}$} & \\
\hline \multirow[t]{2}{*}{ Parallel } & & & $\begin{array}{c}\text { 4: development } \\
\text { of white spot and } \\
\text { cavity. }\end{array}$ & & \\
\hline & & & Photograph & & \\
\hline \multicolumn{6}{|l|}{ Kirschneck et al., [27] } \\
\hline 90 patients & $\begin{array}{c}\text { Test group 1: } 30 \text { patients } \\
\text { with } 1 \text { application of fluoride } \\
\text { varnish Elmex® at the } \\
\text { beginning of the orthodontic } \\
\text { treatment }\end{array}$ & \multirow{3}{*}{$\begin{array}{c}\text { Measures } \\
\text { were done on } \\
\text { week } 4,12 \\
\text { and } 20\end{array}$} & $\begin{array}{l}\text { 0: Sound } \\
\text { 1: White spot } \\
\text { seen after air } \\
\text { drying }\end{array}$ & $\begin{array}{l}\text { None of the } 3 \text { studied groups } \\
\text { showed significant differences } \\
\text { in ICDAS scores on any of the } \\
4 \text { measured times (T0 to T3). } \\
\text { However, the median of the ICDAS } \\
\text { index increased in the three groups } \\
\text { during the period of study (T0 to T3) }\end{array}$ & $\begin{array}{l}\text { The one-time application of Elmex } \\
\text { Fluid® or Fluor Protector S varnishes } \\
\text { at the beginning of the orthodontic } \\
\text { treatment with fixed multibracket } \\
\text { appliance did not provide any } \\
\text { additional benefit in prevention } \\
\text { compared to the home use of } \\
\text { fluoride toothpaste in patients with } \\
\text { low to moderate risk of caries. }\end{array}$ \\
\hline \multirow[t]{2}{*}{ Randomized clinical trial } & & & \begin{tabular}{|} 
4: Underlying \\
dark shadow from \\
dentin 5: \\
Distinct cavity with \\
visible dentin less \\
than $50 \%$
\end{tabular} & \multirow[t]{2}{*}{$\begin{array}{l}\text { White spot lesion (WSL)and initial } \\
\text { caries were significantly greater in } \\
\text { the control group (only oral hygiene } \\
\text { with fluoride toothpaste is enough, } \\
\text { placebo varnish). }\end{array}$} & $\begin{array}{l}\text { Therefore, the application of } \\
\text { the studied varnishes does not } \\
\text { guarantee absolute protection } \\
\text { against the development of white } \\
\text { spot lesions. A progression of } \\
\text { gingival inflammation is not expected } \\
\text { within the first } 5 \text { months after } \\
\text { beginning treatment in patients with } \\
\text { good oral hygiene. Patients and } \\
\text { legal representatives should be fully } \\
\text { informed about the importance of } \\
\text { adequate preventive measures at } \\
\text { home, as well as the risk of enamel } \\
\text { demineralization during orthodontic } \\
\text { treatment with fixed appliances. }\end{array}$ \\
\hline & $\begin{array}{l}\text { Control group: } 30 \text { patients } \\
\text { with 1-time application of } \\
\text { a placebo free of fluoride } \\
\text { at the beginning of the } \\
\text { orthodontic treatment }\end{array}$ & & ICDAS & & \\
\hline \multicolumn{6}{|c|}{ He et al,. [28] } \\
\hline 240 patients (597 teeth) & $\begin{array}{c}\text { Test group 1: upper anterior } \\
\text { teeth of } 80 \text { patients, } \\
\text { application of Duraphat } 1 \\
\text { time per month }\end{array}$ & \multirow{4}{*}{$\begin{array}{c}\text { Measures } \\
\text { were done at } \\
0,3 \text { y } 6 \text { month }\end{array}$} & \multirow{3}{*}{$\begin{array}{l}\Delta \mathrm{F}(\%) \text { : is the } \\
\text { percentage of } \\
\text { fluorescence } \\
\text { loss, comparing } \\
\text { sound enamel } \\
\text { with a lesion. } \\
\text { The fluorescence } \\
\text { loss less than } 5 \% \\
\text { was considered } \\
\text { harmful. Area } \\
\text { (mm }{ }^{2} \text { ) is } \\
\text { calculated as } \\
\text { pixels considered } \\
\text { by the software } \\
\text { to represent } \\
\text { demineralized } \\
\text { enamel (i.e., those } \\
\text { with fluorescence } \\
\text { loss of } 5 \% \text { or } \\
\text { more). } \Delta \mathrm{Q} \text { (mm }{ }^{2} \\
\mathrm{x} \%) \text { is the product } \\
\text { of } \Delta \mathrm{F} \text { and the } \\
\text { area and indicates } \\
\text { the volume of the } \\
\text { lesion. }\end{array}$} & \multirow{2}{*}{$\begin{array}{l}\text { Significant decrease in } \Delta Q \text { in } \\
\text { all groups after } 6 \text { months. In the } \\
\text { statistical analysis, the interaction } \\
\text { between the group and time } \\
\text { indicated that the } \Delta Q \text { values of the } 3 \\
\text { groups followed different trends over } \\
\text { time (varnish vs. control: estimate, } \\
-11.83 ; 95 \% \mathrm{Cl}:-15.39 \text { a }-8.26, P \\
<0.0001, \text { the film against Control: } \\
\text { estimate, }-7.72,95 \% \mathrm{Cl},-11.34 \text { to } \\
-4.10, \mathrm{P}<0.0001, \text { Table IV). }\end{array}$} & \multirow{4}{*}{$\begin{array}{l}\text { White spot lesions around the } \\
\text { brackets may self-healing in } \\
\text { some cases, after removal of the } \\
\text { brackets. However, not all patients } \\
\text { experienced remineralization by } \\
\text { themselves. Daily use of fluoride } \\
\text { toothpaste and education in oral } \\
\text { hygiene can support enamel } \\
\text { remineralization and treatment } \\
\text { with fluoride varnish or a fluoride } \\
\text { film can induce greater amount of } \\
\text { remineralization after orthodontic } \\
\text { treatment. Fluoride varnish may be } \\
\text { slightly more effective than fluoride } \\
\text { film. }\end{array}$} \\
\hline $\begin{array}{l}\text { Durphat/ fluoride film } \\
\text { Sheer/ placebo without } \\
\text { fluoride }\end{array}$ & $\begin{array}{c}\text { Test group 2: upper } \\
\text { anterior teeth of } 80 \text { patients, } \\
\text { application of fluoride film } \\
\text { (Sheer) } 1 \text { time a month }\end{array}$ & & & & \\
\hline Randomized clinical trial & \multirow[t]{2}{*}{$\begin{array}{l}\text { Control group: upper } \\
\text { anterior teeth of } 80 \text { patients, } \\
\text { application of placebo } 1 \\
\text { time a month }\end{array}$} & & & $\begin{array}{l}\text { Decreases in } \Delta Q \text { values among the } \\
3 \text { groups were statistically significant } \\
\text { after adjusting confounding factors. } \\
\text { Other comparisons by peers showed } \\
\text { that the } \Delta Q \text { values of the varnish } \\
\text { and film groups were significantly } \\
\text { reduced more than those of the } \\
\text { control group ( } P<0.0001 \text { for both } \\
\text { comparisons). In addition, the } \Delta Q \\
\text { of the varnish group decreased } \\
\text { significantly higher than that of the } \\
\text { film group }(P=0.0266) \text {. }\end{array}$ & \\
\hline Parallel & & & QLF (images) & & \\
\hline Miresmaeili et al., [29] & & & & & \\
\hline
\end{tabular}


Citation: Sandra CD, Maria D, Ingrid MD, Vanessa HD, Katia VR, et al. (2018) Preventing and Arresting the Appearance of White Spot Lesions around the Bracket by applying Fluoride Varnish: A Systematic Review. Dentistry 8: 500. doi:10.4172/2161-1122.1000500

\begin{tabular}{|c|c|c|c|c|c|}
\hline $\begin{array}{c}65 \text { teeth in } 20 \\
\text { patients }\end{array}$ & \multirow{2}{*}{$\begin{array}{l}\text { Test group: } 10 \text { patients (33 } \\
\text { teeth) Fluoride varnish }\end{array}$} & \multirow{4}{*}{$\begin{array}{c}\text { Measures } \\
\text { were done at } 0 \\
\text { and } 4 \text { months }\end{array}$} & $\begin{array}{l}\text { The pre- and } \\
\text { post-intervention }\end{array}$ & \multirow{4}{*}{$\begin{array}{l}\text { Oral hygiene was good in both } \\
\text { groups. The mean size of the lesion } \\
\text { in the test group was } 8.3 \% \pm 3.07 \\
\text { before treatment, decreasing to } 5.9 \% \\
\pm 2.9 \text { after treatment }(P=0.009) \text {. } \\
\text { The mean size of the lesion in the } \\
\text { control group was } 7.7 \% \pm 4.2 \text { before } \\
\text { treatment, decreasing to } 5.9 \% \pm \\
3.6 \text { after treatment }(P=0.001) \text {. No } \\
\text { statistically significant differences } \\
\text { were detected between the two } \\
\text { groups }(P=0.307) \text {. }\end{array}$} & \multirow{4}{*}{$\begin{array}{l}\text { Based on the results, the application } \\
\text { of fluoride varnish has no superiority } \\
\text { over the process of natural } \\
\text { remineralization of saliva in reducing } \\
\text { the size of white spot lesion on the } \\
\text { enamel in patients with good oral } \\
\text { hygiene. }\end{array}$} \\
\hline $\begin{array}{c}\text { Fluoride varnish } \\
\text { (VOCO)/ } \\
\text { prophylaxis }\end{array}$ & & & $\begin{array}{l}\text { images were } \\
\text { superimposed } \\
\text { using the same }\end{array}$ & & \\
\hline $\begin{array}{l}\text { Randomized } \\
\text { clinical trial }\end{array}$ & \multirow[t]{2}{*}{$\begin{array}{l}\text { Control group: } 10 \text { patients } \\
\text { ( } 32 \text { teeth). No application } \\
\text { of any product, just dental } \\
\text { prophylaxis }\end{array}$} & & $\begin{array}{l}\text { match the two } \\
\text { images. Edges } \\
\text { of the lesion } \\
\text { were marked } \\
\text { before and after } \\
\text { treatment with } \\
\text { black and red } \\
\text { lines, respectively. } \\
\text { The lesion / tooth } \\
\text { area ratio was } \\
\text { calculated based } \\
\text { on the number of } \\
\text { pixels using the } \\
\text { following formula: } \\
\text { WSA } \% \text { Number } \\
\text { of pixels occupied } \\
\text { by the lesion / } \\
\text { Number of pixels } \\
\text { on the surface of } \\
\text { the labial tooth } \\
100\end{array}$ & & \\
\hline Parallel & & & $\begin{array}{l}\text { Photos } \\
\text { superimpose in } \\
\text { photoshop }\end{array}$ & & \\
\hline \multicolumn{6}{|c|}{ Wulc et al., [31] } \\
\hline 20 patients & $\begin{array}{l}\text { Test group: } 10 \text { patients with } \\
\text { fluoride varnish application } \\
\text { in white spot lesion }\end{array}$ & \multirow{3}{*}{$\begin{array}{l}\text { Measures } \\
\text { were done at } 0 \\
\text { and } 2 \text { months }\end{array}$} & $\begin{array}{c}\text { ICDAS } \\
0: \text { Sound } \\
\text { 1: White spot seen } \\
\text { after air drying } \\
\text { for } 5 \text { seconds } \\
\text { 2: White spot } \\
\text { seen when wet. }\end{array}$ & \multirow{3}{*}{$\begin{array}{l}\text { ICDAS median, Code count } 1 \\
\text { and } 2 \text { was } 2.71 \text { with a range from } \\
0 \text { to } 12 \text { and a standard deviation } \\
\text { of } 3.58 \text { in the control group. In } \\
\text { the experimental group the mean } \\
\text { ICDAS count of codes } 1 \text { and } 2 \text { was } \\
6.72 \text { with a range from } 0 \text { to } 17 \text { and a } \\
\text { standard deviation of } 6.69\end{array}$} & $\begin{array}{l}\text { Data collection should be completed } \\
\text { and sample size increased to make } \\
\text { conclusions about the role of fluoride } \\
\text { varnish application in white spot } \\
\text { lesions. Applying fluoride varnish } \\
\text { to white spot lesions appears to be } \\
\text { ineffective in reducing the lesions } \\
\text { compared to good oral hygiene. }\end{array}$ \\
\hline $\begin{array}{c}\text { Fluoride varnish Enamel } \\
\text { Pro®/ without fluoride } \\
\text { varnish application }\end{array}$ & & & $\begin{array}{l}\text { QLF Three } \\
\text { images were } \\
\text { taken for each }\end{array}$ & & \\
\hline Randomized clinical trial & $\begin{array}{l}\text { Control group: } 10 \\
\text { patients with oral hygiene } \\
\text { instructions }\end{array}$ & & $\begin{array}{c}\text { patient. } 2 \\
\text { images of buccal } \\
\text { segments and } 1 \\
\text { front image. Loss } \\
\text { of fluorescence } \\
\text { (Df) and changes } \\
\text { in caries volume } \\
(\Delta Q) \text { were } \\
\text { calculated with } \\
\text { QLF - D software } \\
\text { by tracing all } \\
\text { lesion. }\end{array}$ & & $\begin{array}{l}\text { There can be no correlation between } \\
\text { IMC and the susceptibility to white } \\
\text { spots. Changes } \\
\text { in patient recruitment and } \\
\text { appointments could enhance the } \\
\text { data collection process, allowing a } \\
\text { successful long-term experiment }\end{array}$ \\
\hline Restrepo et al., [32] & & & & & \\
\hline
\end{tabular}


Citation: Sandra CD, Maria D, Ingrid MD, Vanessa HD, Katia VR, et al. (2018) Preventing and Arresting the Appearance of White Spot Lesions around the Bracket by applying Fluoride Varnish: A Systematic Review. Dentistry 8: 500. doi:10.4172/2161-1122.1000500

Page 7 of 10

\begin{tabular}{|c|c|c|c|c|c|}
\hline 30 patients (51 lesions) & & \multirow{5}{*}{$\begin{array}{l}\text { At the moment } \\
\text { of application, } \\
1 \text { week, } 1,2, \\
3 \text { months after } \\
\text { application. }\end{array}$} & \multirow{3}{*}{$\begin{array}{l}\text { Diagnodent: } \\
\text { Previously } \\
\text { calibrated } \\
\text { measuring sound } \\
\text { surface of each } \\
\text { tooth. Measures } \\
\text { were performed } \\
\text { after air drying } \\
\text { for } 5 \text { seconds. } \\
\text { The peak reading } \\
\text { shown on the } \\
\text { DDpen panel was } \\
\text { recorded twice } \\
\text { for each tooth } \\
\text { surface. }\end{array}$} & \multirow[b]{2}{*}{$\begin{array}{l}\text { Fluorescence values decreased } \\
\text { during the course of the study. The } \\
\text { average reading of the lesions in } \\
\text { DDpen on the baseline F group: } 17.2 \\
\pm 2.3, \mathrm{CHX} \text { group: } 16.8 \pm 1.8, \mathrm{CO} \\
\text { group: } 17.0 \pm 1.7 \text {, which decreased } \\
\text { to } 7,2,9.2 \text { and } 10.5 \text {, respectively, at } \\
\text { the end of the study ( } 3 \text { months). }\end{array}$} & \multirow{5}{*}{$\begin{array}{l}\text { After } 3 \text { months, } \mathrm{F}, \mathrm{CHX} \text { or } \mathrm{CO} \\
\text { groups were able to control white } \\
\text { spot lesions around to the bracket. } \\
\text { However, the treatment with fluoride } \\
\text { varnish was able to control the } \\
\text { progression of the lesion in a shorter } \\
\text { period of time. }\end{array}$} \\
\hline $\begin{array}{l}\text { 5\% NaF Varnish } \\
\text { (Duraphat } ₫ \text { ) }\end{array}$ & $\begin{array}{c}\text { Test group 1: F group: } 5 \% \\
\text { NaF varnish: } 10 \text { patients, } 17 \\
\text { lesions }\end{array}$ & & & & \\
\hline $\begin{array}{l}\text { 2\% Chlorhexidine gel } \\
\text { (Clorexal gel } 2 \%)\end{array}$ & \multirow[t]{2}{*}{$\begin{array}{l}\text { Test group 2: CHX group: } \\
2 \% \text { Chlorhexidine gel: } 10 \\
\text { patients, } 17 \text { lesions }\end{array}$} & & & $\begin{array}{l}\text { At the end of the study, } 70.58 \% \\
\text { of the lesions were classified as } \\
\text { inactive with intact surface (NY, } \\
\text { score } 4 \text { ) and } 29.42 \% \text { as active with } \\
\text { intact surface (NY, score 1). }\end{array}$ & \\
\hline Saline solution & & & & One week after the first application, & \\
\hline Randomized clinical trial & $\begin{array}{c}\text { Control group: CO group: } \\
\text { Saline solution: } 10 \text { patients, } \\
17 \text { lesions }\end{array}$ & & $\begin{array}{l}\text { Nyvad Index: } \\
\text { 0: Sound } \\
\text { 1: Active caries } \\
\text { (intact surface) } \\
\text { 2: Active caries } \\
\text { (superficial } \\
\text { discontinuity) } \\
\text { 3: Active } \\
\text { caries (cavity) } \\
\text { 4: Inactive caries } \\
\text { (intact surface) }\end{array}$ & $\begin{array}{l}\text { fluorescence values in } F \text { group } \\
\text { were significantly lower than those } \\
\text { at baseline }(P<0.01) \text { and } C H X \\
(P<0.01) \text {. Significant differences } \\
\text { in baseline were found only for } \\
\text { the control group one week after } \\
\text { the second application }(P<0.01) \text {. } \\
\text { Fluorescence values for } F \text { remained } \\
\text { constant from the 1st to 3rd month } \\
\text { and were significantly different from } \\
\text { baseline }(P<0.05) \text {. At the third } \\
\text { month, fluorescence values for } F \\
\text { were similar to } C H X(P>0.05) \text { but } \\
\text { were significantly different from CO } \\
(P<0.05) \text {. However, } \mathrm{CHX} \text { values } \\
\text { were similar to } C O \text { values }(P>0.05) \text {. }\end{array}$ & \\
\hline
\end{tabular}

Table 3: Characteristics of the included studies in arresting white spot lesions with fluoride varnish applications.

conventional oral hygiene and toothpaste regimen for remineralization of white spot lesions over a period of 8 weeks. In contrast, StecksénBlicks et al. [27], affirmed that regular applications of topical fluoride varnish can reduce the development of white spot lesions along the periphery of the bracket during treatment with orthodontics fixed appliances.

Therefore, fluoride varnish should be considered as a professional preventive measure in orthodontics practice.

Demito et al. [24], showed 32\% more progression of demineralization in the control group than in the varnish group at six months; however, the differences were not statistically significant. Likewise, they affirmed that the greatest demineralization occurred in the gingival third [24,31].

One of the evaluated studies found that the incidence of WSL with fluoride varnish application during the treatment with orthodontics fixed appliances was $7.4 \%$, while it was $25.3 \%(p<0.001)$ in the placebo group, and the absolute risk reduction was $18 \%$. The progression was significantly lower in the fluoride varnish group than in the placebo group, $0.8+/-2.0 \%$. $2.6+/-2.8(p \leq 0.001)$ [25]. Likewise, Perrini et al. [31], reported similar results, concluding that there was a greater tendency towards demineralization in the untreated vs. the treated teeth, although statistical analysis showed that the difference was not significant at any of the measurement times. Therefore, at 9 months of follow-up, the treated incisors showed significantly less demineralization than the previous non-varnished (untreated) teeth.

Assessment of the effectiveness of fluoride varnish to arrest white spot lesions: Four of the 10 studies [23,28-30], agreed that good oral hygiene associated with the use of fluoride toothpaste was able to remineralize white spot lesions and did not find statistically significant differences in the progress or detention of the lesions with fluoride varnish application compared to other techniques, suggesting that the use of fluoride varnish does not have superiority in the remineralization of white spot lesions in relation to oral hygiene reinforcement.



Figure 2: Summary of the bias risk of included studies in the synthesis. 
Kirschneck reported that between the Elmex fluid group, the Fluor Protector S group and the placebo group without fluoride, there was no significant difference in the measurements at any of the four evaluated times (T0 to T3). However, the mean ICDAS index significantly increased in the three groups during the course of the investigation (T0 to T3), and WSL and initial caries were significantly higher in the control group, which had only oral hygiene with fluoride toothpaste, and a placebo varnish [29].

Likewise, Miresmaeili et al. [28], showed good oral hygiene in both the fluoride varnished and the prophylaxis group, the mean lesion size in the test group was $8.3 \% \pm 3.07$ before treatment, decreasing to $5.9 \% \pm$ 2.9 after treatment ( $p=0.009$ ), and in the control group, the mean lesion size was $7.7 \% \pm 4.2$ before treatment, decreasing to $5.9 \% \pm 3.6$ after treatment $(p=0.001)$; however, no statistically significant differences were detected between the groups ( $p=0.307$ ).

In contrast, $\mathrm{He}$ et al. reported a significant decrease in white spot lesions in all groups after 6 months. The interaction between the group and time in the statistical analysis indicated that the values of the 3 groups followed different trends in time (varnish vs. control: estimate, -11.83 ; $95 \%$ CI: -15.39 to $-8,26, p<0.0001$, the fluoride vs. control film: estimation, $-7.72,95 \% \mathrm{CI},-11.34$ to $-4.10, p<0.0001)$. It should also be noted that the authors emphasized the importance of explaining to patients and families about the risks of acquiring white spot lesions around the brackets during orthodontic treatment, taking into account oral hygiene care and the use of fluoride toothpastes.

Effectiveness of fluoride varnish application versus other therapies to prevent and arrest white spot lesions

Huang et al. did not find differences between the effectiveness of MI Paste Plus and PreviDent fluoride varnish compared to conventional oral hygiene and the use of toothpaste for the remineralization of white spots during a period of 8 weeks [22]. Stecksen-Blicks et al. stated that regular applications of topical fluoride varnish versus placebo may reduce the development of white spot lesions around the bracket during treatment with orthodontics fixed appliances, and then, the fluoride varnish can be used as a preventive measure as a professional routine in the practice of orthodontics [27].

Huang et al., noted that the improvements in white spot lesions evaluated by the expert panel were 29\% MI Paste Plus, 31\% Fluoride in PreviDent Varnish and 25\% in the untreated group; however, there were no statistically significant differences. In contrast, Restrepo et al. reported that after 3 months, the $5 \% \mathrm{NaF}$ varnish-F (Duraphat ${ }^{\circledR}$ ) group, $2 \%$ chlorhexidine Gel and the saline-treated control group were able to control white spot lesions around the brackets. However, treatment with $5 \% \mathrm{NaF}$ varnish was able to control the progression of the lesion in a shorter period of time $[22,26]$.

\section{Discussion}

\section{Summary of main findings}

Overall, most of the included studies did not show significant advantages of fluoride varnish application in terms of preventing the development of white spots around orthodontic brackets when the patients were submitted to regular professional oral hygiene control.

Taking into account that the fluoride varnishes are made by different commercial manufacturers, the composition of the product can vary, mainly in the proportions of fluoride. However, the articles evaluated in this review presented the application protocols of fluoride varnish according to the criteria of each manufacturer.

\section{Quality of evidence and potential biases and limitations in the review process}

The studies included in this review showed differences in methodological quality, with greater control of bias in 6 of them [22,23,26-30] and 4 with moderate methodological quality [24,25,28,31]. Three studies used the same diagnostic method (Diagnodent). However, the evaluation scale to characterize the lesions had a different value. Likewise, other authors performed a photographic analysis of the lesions, but each one used different software and criteria to classify WSL. It is important to emphasize that none of the studies evaluated stated a conflict of interest $[22,25,27,28]$.

Due to the heterogeneity of the measured parameters and the instruments used, an important methodological problem was generated for interpretation of the results, taking into account the variability of the measures used to determine white spot lesions. This allowed only the generation of qualitative analyses about the impact of fluoride varnishes on initial caries lesions.

According to the International Caries Classification and Management System (ICCMS), the time of fluoride varnish applications changes regarding the patient's level of risk for developing caries. Based on this, they recommend an average application of fluoride varnish twice a year in individuals with medium risk and 4 times a year in patients with high risk of development caries [32]. On the other hand, ICCMS mentions that for patients with a low risk of dental caries, it is not necessary to apply fluoride varnish, and only adequate oral hygiene is required, which agrees with the studies evaluated in this review. However, it is necessary to emphasize that this protocol is not standardized for patients with orthodontic appliances in which oral hygiene is more difficult to perform but is aimed at individuals in general.

The studies included in this systematic review used fluoride varnishes from different commercial manufacturers as follows: Bifluoride [33,34], PreviDent fluoride varnish, Elmex fluid, Duraphat, Fluor Protector S, 5\% NaF Varnish-F [35-39]. However, the application methods were similar, since they were all applied on dry surfaces and were left to act on the dental surface as a biofilm without any kind of removal. Additionally, concentrations of fluoride levels varied from one to another as follows: Duraphat, PreviDent 5\% and $\mathrm{NaF}$ Varnish-F have 22,600-ppm concentrations; while Fluor Protector S has a 7,700-ppm fluoride concentration, and ELMEX has a 1,200-ppm concentration, suggesting that these various concentrations of fluoride may directly influence the results obtained by the studies.

On the other hand, each varnish has a different coloring. In studies that used a placebo and a fluoride varnish with different pigments, such as Duraphat, the examiners could not be blinded, which could have generated biases in the measurements. Another difference between commercial manufacturers is the total amount of product contained in the bottle and the type of storage used; however, the authors did not report whether these characteristics influenced the results.

The included studies showed different diagnostic methods, making it difficult to associate and compare the results. Therefore, performing a meta-analysis was not possible. Additionally, finding articles with a high evidence level was complex.

\section{Agreements and disagreements with other studies or reviews}

It is important to emphasize that, so far, there are no specific systematic reviews of the studied subject. However, there have been 
Citation: Sandra CD, Maria D, Ingrid MD, Vanessa HD, Katia VR, et al. (2018) Preventing and Arresting the Appearance of White Spot Lesions around the Bracket by applying Fluoride Varnish: A Systematic Review. Dentistry 8: 500. doi:10.4172/2161-1122.1000500

studies that evaluated the progression of white spot lesions with other prevention methods, even with fluoride varnish in combination with other materials such as chlorhexidine.

Øgaard B et al. evaluated the effectiveness of fluoride varnish in combination with an antimicrobial agent and compared it with only a fluoride varnish in the reduction of white spot lesions [16]. They found that a fluoride varnish combined with the antimicrobial agent reduced the levels of Streptococcus and other bacteria in the plaque during the first 48 hours, but for the reduction of white spot lesions, no statistically significant differences were observed between the two groups.

Benson PE et al., in their systematic review, evaluated the effects of fluoride on reducing the incidence of white spot lesions in teeth during orthodontic treatment, assessing several methods of prevention [39]. They found that the application of fluoride varnish every six weeks during orthodontic treatment was effective to prevent WSL. They concluded that more double-blind, randomized and controlled studies are necessary to determine the best way to prevent white spot lesions in patients undergoing orthodontic treatment, as well as the most accurate way of assessing compliance on treatment and possible adverse effects, which agreed with the results of this new systematic review.

The results found in this review were similar to those in the report by Baygin et al., in which they evaluated the effect of the chlorhexidinethymol varnish, a fluoride varnish with chlorhexidine of toothpaste, the fluoride varnish in oral hygiene and the prevention of dental caries in patients with orthodontic applications [39]. The authors found that the use of Cervitec Plus or Cervitec gel, combined with the standard oral hygiene regimen, may be beneficial in orthodontic patients for maintenance of oral health by reducing bacterial colonization and gingivitis.

Based on the above, this review suggests that for future studies, the protocol for the application of fluoride varnish should be standardized, taking into account the periods of application for high risk individuals, such as patients with orthodontic appliances. Therefore, we recommend the parameters of ICCMS for the fluoride varnish application protocol in this type of patient (every three months for high risk patients).

In all but 4 studies included in this review, patients were aware that they were being evaluated, so a Hawthorne effect may be present, where patients were blinded. In addition, it can be inferred that patients were meticulously instructed to perform their oral hygiene routine, so the presence of plaque may have been lower. For unbiased results regarding the effectiveness of fluoride varnishes, the effects of fluoride should be studied with basic oral hygiene instructions that reflect the reality of the daily consultation $[23,26,27,30]$.

\section{Conclusions}

Fluoride varnish seems to be an effective material to prevent and arrest white spot lesions in patients with orthodontic treatment who are at high risk of developing these lesions due to poor oral hygiene. However, neither statistical nor clinical advantages to fluoride varnish application in terms of preventing the development of white spots around orthodontic brackets could be identified when the patients followed a regular professional oral hygiene control routine.

\section{Implications for practice and directions for future research}

Professional guidance for oral hygiene is enough to prevent or arrest white spot lesions around brackets.

Future clinical trials should evaluate the effectiveness of a varnish under true oral hygiene conditions so that it is possible to quantify the application of these materials and to develop a standardized protocol for the application of fluoride varnish for patients with orthodontic treatment.

\section{References}

1. Sangamesh B, Kallury A (2011) Latrogenic effects of Orthodontic treatmentReview on white spot lesions. Int J Sci Eng Res 2: 1-6.

2. Summit JB, Robbins JW (2006) Fundamentals of operative dentistry: Acontemporary approach. In: Fundamentals of operative dentistry: Acontemporary approach, ed 3.

3. Guagnani N, Pandit IK, Gupta M (2012) Caries infiltration of noncavitated white spot lesions: A novel approach for immediate esthetic improvement. Contemp Clin Dent 3: 199-202.

4. Maxfield BJ, Hamdan AM, Tüfekci ES (2012) Development of white spot lesions during orthodontic treatment: perceptions of patients, parents, orthodontists and general dentists. Am J orthdontics Dentofac Orthop 141: 337-344.

5. Benson PE, Parkin N, Dyer F, Millett DT, Furness S (2013) Fluorides for the prevention of early tooth decay (demineralised white lesions) during fixed brace treatment. Cochrane Database Syst Rev 12: 3809

6. Lussi A, Imwinkelried S, Pitts N, Longbottom CRE (1999) Performance and reproducibility of a laser fluorescence system for detection of occlusal caries in vitro. Caries Res 33: 261-266.

7. Cochrane NJ1, Walker GD, Manton DJ (2012) Comparison of quantitative lightinduced fluorescence, digital photography and transverse microradiography for quantification of enamel remineralization. Aust Dent J 57: 271-276.

8. Kavo. Diagnodent pen [Internet]. 2017. Available from: https://www.kavo.com/ en-us/search/diagnodent

9. Zachrisson BU, Brobakken BO (1978) Clinical comparison of direct versus indirect bonding with different bracket types and adhesives. Am J Orthod 74 62-78

10. Mizrahi E (1982) Enamel demineralization following orthodontic treatment. Am J Orthod 82: 62-67.

11. Enaia M, Bock N, Sabine R (2011) White-spot lesions during multibracket appliance treatment: A challenge for clinical excellence. Am J Orthod Dentofac Orthop 140: e17-e24

12. Ferreira JMS, Ramalho Aragão AK (2009) Therapeutic effect of two fluoride varnishes on white spot lesions: a randomized clinical trial. Braz Oral Res 23 446-451.

13. Murray JW (1992) No Title. In: Ecology and distribution of benthic foraminifera p. 221-253.

14. Ripa LW WM (1992) Preventive resin restorations: indications, technique, and success. Quintessence Int (Berl) 23: 307-315.

15. Fernández CE, Tenuta LM, Zárate P CJ (2014) Insoluble NaF in Duraphat $\AA$ may prolong fluoride reactivity of varnish retained on dental surfaces. Braz Dent J 25: 160-164.

16. Øgaard B, Larsson E, Henriksson T, Birkhed D BS (2001) Effects of combined application of antimicrobial and fluoride varnishes in orthodontic patients. Am J Orthod Dentofac Orthop 120: 28-35.

17. Marinho VC1, Worthington HV, Walsh T CJ (2013) Fluoride varnishes for preventing dental caries in children and adolescents. Cochrane Database Syst Rev 11: 2279

18. GL V (2011) Oral fluoride reservoirs and the prevention of dental caries. Monogr Oral Sci 22: 146-157.

19. Moher D, Liberati A, Tetzlaff J (2009) Methods of systematic reviews and metaanalysis preferred reporting items for systematic reviews and meta-analyses: the PRISMA Statement. J Clin Epidemiol 62: 1006-1012.

20. Higgins JPT, Green S (2008) Cochrane Handbook for Systematic Reviews of Interventions.

21. Higgins JPT GS (2011) Cochrane Handbook for Systematic Reviews of Interventions. Version 5.1.0. Part 2: General methods for Cochrane reviews.

22. Huang GJ, Roloff-Chiang B, Mills BE, Shalchi S, Spiekerman C, et al. (2013) Effectiveness of MI Paste Plus and PreviDent fluoride varnish for treatment of 
Citation: Sandra CD, Maria D, Ingrid MD, Vanessa HD, Katia VR, et al. (2018) Preventing and Arresting the Appearance of White Spot Lesions around the Bracket by applying Fluoride Varnish: A Systematic Review. Dentistry 8: 500. doi:10.4172/2161-1122.1000500

white spot lesions: a randomized controlled trial. Am J Orthod Dentofac Orthop 143: 31-41.

23. DW Reatment Of Orthodontic White Spots: Etiology Of Orthodontic White Spot Lesions And Interventional Fluoride Varnish Treatment: A Randomized Control Trial (Thesis Master of Science in oral biology). Philadelphia.; 2015

24. Demito CF, Rodrigues GV, Ramos AL (2011) Efficacy of a fluoride varnish in preventing white-spot lesions as measured with laser fluorescence. $\mathrm{J}$ Clin Orthod 45: 25-29.

25. Rodrigues G, Demito CF, Bowman SJ R AL (2006) The effectiveness of a fluoride varnish in preventing the development of white spot lesions. World $\mathrm{J}$ Orthod 7: 138-144.

26. Restrepo M, Bussaneli D, Jeremias F, Cordeiro R, Raveli D, et al. (2016) Control of White Spot Lesions with Use of Fluoride Varnish or Chlorhexidine Gel During Orthodontic Treatment A Randomized Clinical Trial. J Clin Pediatr Dent 40: 274-280.

27. Stecksén-Blicks C, Renfors G, Oscarson ND, Bergstrand F TS (2007) Cariespreventive effectiveness of a fluoride varnish: a randomized controlled trial in adolescents with fixed orthodontic appliances. Caries Res 41: 455-459.

28. Miresmaeili A, Farhadian N, Rezaei-soufi L, Saharkhizan M VM (2012) Effect of carbon dioxide laser irradiation on enamel surface microhardness around orthodontic brackets. Am J Orthod Dentofac Orthop 146: 161-165.

29. Kirschneck C, Christl JJ, Reicheneder C PP (2016) Efficacy of fluoride varnish for preventing white spot lesions and gingivitis during orthodontic treatment with fixed appliances-a prospective randomized controlled trial. Clin Oral Investig. Clinical Oral Investigations 20: 2371-2378.

30. He, Li X, Dong Y, Zhang N, Zhong Y, Yin W HD (2016) Comparative assessment of fluoride varnish and fluoride film for remineralization of postorthodontic white spot lesions in adolescents and adults over a 6-month period: A single-center, randomized controlled clinical trial. Am J Orthod Dentofac Orthop 149: 810819.

31. Perrini F, Lombardo L, Arreghini A, Medori S SG (2016) Caries prevention during orthodontic treatment: In-vivo assessment of high-fluoride varnish to prevent white spot lesions. Am J Orthod Dentofac Orthop 149: 238-243.

32. Pitts NB, Ismail AI, Martignon S, Ekstrand K, Douglas GVA, et al. (2014) Guía ICCMSTM para clínicos y educadores. ICDAS Foundation, International Caries Detectión and Assessment System, 1-84.

33. Chapman JA, Roberts WE, Eckert GJ, Kula KS, González-Cabezas C (2010) Risk factors for incidence and severity of white spot lesions during treatment with fixed orthodontic appliances. Am J Orthod Dentofac Orthop 138: 188-194.

34. Colgate. Colgate introduces new and improved PreviDent Varnish formula. [Internet]. 2013.

35. Colgate. Colgate Duraphat Barniz |Resumen|Productos dentales. [Internet] 2016.

36. GmbH M. Fluor Protector S by Ivoclar Vivadent. [Internet]. 2013.

37. 3M. \% Sodium Flouride White Varnish with Tri-Calcium Phosphate|3M United States. [Internet].

38. Benson PE, Shah AA, Millett DT, Dyer F, Parkin N, et al. (2005) Fluorides orthodontics and demineralization: a systematic review. J Orthod 32: 102-114.

39. Baygin O, Tuzuner T, Ozel MB, Bostanoglu O (2013) Comparison of combined application treatment with one-visit varnish treatments in an orthodontic population. Med Oral Patol Oral Cir Bucal 18: e362-e370. 